\title{
Em Brasília, mas em Recife: atravessamentos tecnometodológicos em saúde, gênero e maternidades numa pesquisa sobre as repercussões da epidemia do vírus Zika'
}

In Brasilia, but in Recife: techno-methodological crossings in health, gender and maternities in a research on the Zika virus epidemic's repercussions

\section{Rosamaria Carneiro ${ }^{a}$}

(D) https://orcid.org/0000-0002-1271-7645

E-mail: rosagiatti®yahoo.com.br

\section{Soraya Fleischer ${ }^{\mathrm{b}}$}

(1D) https://orcid.org/0000-0002-7614-1382

E-mail: soraya®unb.br

anniversidade de Brasília. Faculdade de Saúde. Departamento de Saúde Coletiva. Brasília, DF, Brasil.

buniversidade de Brasília. Instituto de Ciências Sociais. Departamento de Antropologia. Brasília, DF, Brasil.

\section{Correspondência}

Soraya Fleischer

Universidade de Brasília, Campus Universitário Brasília.

Brasília, DF, Brasil. CEP 70910-900.

\section{Resumo}

Este artigo discute a prática da pesquisa antropológica em saúde em múltiplas dimensões, a partir de nossa primeira estada de campo entre as mães de bebês com síndrome congênita pelo Zika Vírus no Recife em 2016. Os arranjos metodológicos insurgentes foram tão inovadores e desafiadores que nos impulsionaram a refletir sobre as contribuições da pesquisa para o debate teórico sobre pesquisa social em saúde. Por isso, nessas linhas refletimos sobre a prática de pesquisa etnográfica coletiva; a pluralidade de papéis da docente e pesquisadora; autoria e ética dos diários de campo e resultados da pesquisa; o uso do WhatsApp em campo e como campo; e, por fim, as particularidades de uma pesquisa sobre mães quando as pesquisadoras também são mães e, por meio disso, encontram-se e também distanciam. Um esforço sempre ancorado na ideia de tencionar e fazer alargar o que se entende por práticas de pesquisa, sem, contudo, perder em profundidade, compromisso ético e reflexividade.

Palavras-chave: Metodologia; Ensino; Antropologia; Saúde Coletiva; Maternidade; Vírus Zika.

1 Esta pesquisa contou com recursos da Fundação de Empreendimentos Científicos e Tecnológicos (Finatec), do Departamento de Antropologia e do Decanato de Ensino de Graduação, todos da Universidade de Brasília, e do Conselho Nacional de Desenvolvimento Científico e Tecnológico (CNPq). 


\section{Abstract}

This article discusses the practice of medical anthropological research in multiple dimensions, from our first field visit among mothers of babies with congenital Zika Virus syndrome (SCZV) in Recife in 2016. The insurgent methodological arrangements were so innovative and challenging that impelled us to reflect on the contributions of this research to the more general theoretical debate on social research in health. Therefore, in these lines, we reflect on the practice of collective ethnographic research; the plurality of roles of a teacher and researcher; authorship and ethics in the use of field diaries and research results; the use of WhatsApp in the field and as the field; and, finally, the particularities of a research on mothers when the researchers are also mothers and, through this, they meet and also distance themselves. An effort always anchored in the idea of intending and expanding what is understood by research practices, without, however, losing in depth, ethical commitment and reflexivity.

Keywords: Methodology; Teaching; Anthropology; Public Health; Maternity; Zika Virus.

\section{Primeiras linhas}

Éramos, entre 2016 e 2017, um grupo de mulheres da Universidade de Brasília pesquisando o fenômeno do Zika vírus no Recife/PE e também no Distrito Federal. Éramos professoras e estudantes, dos departamentos de antropologia e de saúde coletiva, duas mães perto dos 40 anos e outras sete jovens mulheres sem filhos, ao redor de 20 anos. ${ }^{2}$ O objetivo de pesquisa era descrever o cotidiano e a semântica de vida e de cuidados oferecidos por mulheres que têm filhos com síndrome congênita pelo Zika Vírus (SCZV, doravante) ou, como elas mesmas se autodefiniam, “mães de micro". Já há um certo acúmulo do aporte antropológico sobre as consequências da epidemia do vírus Zika no país (Lira, 2017; Lira; Scott; Meira, 2017; Pereira et al., 2017; Porto; Costa, 2017; Valim, 2017), mas aqui, nossos esforços serão por refletir sobre como o tema tem sido por nós pesquisado, sobretudo a partir de escolhas coletivas de organização da equipe, contato e condução das trocas com as mães de micro, registro e utilização dos dados construídos.

Entre 2015 e 2016, o Brasil e a América equatorial foram atingidos por uma forte epidemia de Zika, leve como uma infecção clínica, intensa como uma consequência reprodutiva (Plourde; Bloch 2016). Desde então, quase 4 .ooo bebês nasceram em todo o país com graves anomalias fetais a partir da transmissão vertical do vírus Zika, especialmente microcefalia, hidrocefalia, calcificações neurológicas, estrabismo, epilepsia, disfagia etc. Na região Nordeste, a mais afetada por essa arbovirose, os estados da Bahia e de Pernambuco lideraram os casos confirmados, com quase mil bebês nascidos com a SCZV (Brasil, 2019).

Durante os surtos de 2015 e 2016 , Recife foi considerado o epicentro da epidemia e isso nos convenceu a concentrar nossos esforços de pesquisa na região. Como estamos em Brasília, a $2.100 \mathrm{~km}$ de distância, tivemos que desenhar uma estratégia para entrar em contato com mulheres que vivenciaram o nascimento de crianças com o SCZV e estivessem dispostas a conversar com um grupo de

2 As estudantes dessa primeira equipe de pesquisa foram Beatriz Morais, Lays Venâncio, Fernanda Vieira, Verônica Milhomem, Mariah Milhomem, Yazmin Safatle e Thais Souza. As professoras somos nós, autoras do presente texto. 
pesquisadoras que não conheciam e que moravam na capital federal. Desenhamos um projeto de pesquisa, direcionamos alguns pedidos de financiamento e começamos a desenhar as estratégias para, como se diz, "entrar em campo". ${ }^{3}$

Em setembro de 2016, conhecemos um blog destinado à ajuda humanitária dessas famílias ("Cabeça e coração"), ${ }^{4}$ ali encontramos endereços postais de algumas mães de micro, escrevemos cartas postais a essas mulheres, obtivemos respostas e passamos a nos comunicar com algumas delas pelo aplicativo de telefone celular, o WhatsApp. Ou seja, os contatos a partir de Brasília se iniciaram por meio de tecnologias ainda um pouco incomuns na pesquisa antropológica em saúde. Desde então, muitas têm sido as novidades e metodologias ao realizarmos esta pesquisa.

Como docentes e pesquisadoras, neste texto, gostaríamos de privilegiar o início desta longa pesquisa: o seu primeiro semestre, quando toda essa metodologia estava sendo experimentada, inventada e avaliada a um só tempo. Hoje, com o projeto ainda em curso e passados três anos do início do projeto, muito mudou, em termos de equipe, tecnologias, estratégias metodológicas. Ainda assim, achamos que vale a pena resgatar e pensar sobre esses primeiros passos, apostando que há alguns aprendizados em sua artesanalidade e experimentalidade. Aqui, pretendemos refletir sobre alguns desses pontos no que tangencia à "autoridade etnográfica” (Clifford, 2011), à escrita (Geertz, 2009) e aos modus operandi de uma pesquisa de campo em grupo, temas caros ao fazer antropológico e pesquisas sociais em saúde no campo da Saúde Coletiva no século XXI.

Para isso, o texto está organizado da seguinte forma: primeiro, descreveremos como foi proposta, organizada e conduzida uma pesquisa em equipe. Depois, discutiremos o que aconteceu quando a equipe se subdividiu e se afastou geograficamente, ficando com algumas de suas pesquisadoras em Brasília e outras, em Recife, mas em comunicação e trabalho, de modo diário e remoto. Passaremos pelas tecnologias mais recentes de telefones celulares (aplicativos de mensagens), mas também alinhavaremos com as tecnologias mais comuns na pesquisa antropológica, como os cadernos e diários de campo, as cartas, e-mails e telefonemas. Um terceiro plano de discussão, que nos apareceu com força nesses arranjos de pesquisa, foi a maternidade, presente e também remota, e seus desafios para pesquisadoras mulheres e mães de crianças ainda pequenas. Por fim, queremos pensar sobre os efeitos da pesquisa em equipe para as práticas docentes e para a produção de conhecimento antropológico e sobre a saúde enquanto fenômeno social.

\section{Fazendo etnografia em grupo}

Dos escritos de gabinete, como nos conta Clifford (2011), os antropólogos do começo do século XX passaram às viagens e ao exercício da etnografia, buscando os dados por si mesmos e não mais escrevendo à luz dos diários de bordo de missionários e clérigos ou viajantes e aventureiros da época das grandes navegações. Quando remontamos às obras clássicas, que são consideradas fundantes da área, como Os argonautas do Pacífico Ocidental (Malinowski, [1922]1976), Sexo e temperamento (Mead, [1935]1969) ou Os Nuer (Evans-Pritchard, [1940]1978), deparamonos com pesquisas individuais, com o antropólogo ou a antropóloga vivendo sozinho(a) o desafio da pesquisa de campo, das barreiras da língua, do estranhamento, das estratégias de aproximação e do "choque cultural" (Wagner, 2010). Contavam, no máximo, com intérpretes ou tradutores(as) do idioma que pouco conheciam ao chegarem a determinadas sociedades; ao menos, é isso que se percebe nos escritos de Clastres (1986), Evans-Pritchard ([1940]1978), Benedict (200o) e por aí afora. Poderse-ia pensar, portanto, que a ideia de trabalho de campo vai se canonizando como algo individualizado, personalizado e, que, depois, inclusive, caracterizará aquele(a) pesquisador(a) como especialista em um tema ou junto a uma determinada sociedade.

\footnotetext{
3 CAAE: 60509116.0.0000.5540

40 blog não está mais no ar (http://cabecaecoracao.com/). Embora desconheçamos a razão, os endereços postais foram retirados do blog depois de algum tempo.
} 
Passando desse cenário que se tornou canônico na história da disciplina, com o trabalho sendo feito individualmente, chegamos a formatos mais coletivos nos dias atuais. No caso de nossa pesquisa, meia dúzia de cartas foi enviada, sobretudo às mulheres que, no blog referido, se identificavam como moradoras do município de Recife, para tentarmos circunscrever um pouco mais geograficamente o raio da pesquisa. Na carta, apresentamos nossa equipe e o objetivo da pesquisa, deixamos nossos contatos, caso concordassem em continuarmos em diálogo. Face ao nosso endereço postal, telefones (fixo e celular) e WhatsApp, elas optaram por esse último meio de comunicação. Esse é um meio que mais comumente essas mulheres adotaram para o apoio mútuo diante da epidemia, como bem já mostraram outras pesquisadoras (Diniz, 2016; Lira; Scott; Meira, 2017). Três mulheres nos responderam, mas somente duas delas, de fato, empreenderam conversações conosco. A terceira só respondia nossas interpelações com emojis.

Esses contatos com as mulheres recifenses foram sendo apresentados nas reuniões semanais da equipe em Brasília, com o pacto de confidencialidade dos dados entre suas participantes. Isso quer dizer, na prática, que não deveríamos divulgar, para fora da equipe de pesquisa, as informações que eram socializadas durante as reuniões. Mas, mesmo que as mulheres em Recife soubessem que éramos pesquisadoras e estávamos numa relação de pesquisa, mesmo que tenhamos explicado que conversas (inclusive por aplicativo de celular), entrevistas e observações compõem os nossos materiais de pesquisa, não sabemos ao certo ainda se elas compreendem se tratar também de "pesquisa" a dinâmica de trazer um trecho ou uma informação de uma conversa de WhatsApp entre três de nós que participavam do grupo virtual formado no aplicativo para uma reunião presencial entre nove de nós. Por mais que expliquemos nossos passos metodológicos e por mais que elas estejam cada vez mais familiarizadas com a presença de cientistas pesquisando o vírus Zika em Recife, talvez imaginar como funciona uma universidade, uma equipe de pesquisa, uma transcrição de uma conversa e uma reunião de análise de dados não sejam realidades muito familiares para muitas de nossas interlocutoras. São questões éticas que têm surgido ao longo da pesquisa e que precisarão de mais trato futuro. Por enquanto, junto a elas (interlocutoras e também estudantes), vamos esclarecendo e traduzindo as etapas que constituem nosso trabalho acadêmico.

Alguns trechos mais eloquentes das conversas por WhatsApp foram discutidos, perfis sociológicos sobre essas mães de micro começaram a ser esboçados, comparações entre diferentes experiências entre elas foram ensaiadas. Essas primeiras reflexões feitas em grupo eram levadas de volta à conversa no aplicativo, inspirando novas perguntas e interpelações às duas mulheres que permitiram se deixar conhecer. As mães de micro foram nos "dando trela", contando de suas vidas e das histórias que seus(suas) filhos(as) vinham enfrentando em consultórios médicos, clínicas de reabilitação, transporte público e também dentro da própria casa. Nessa troca de mensagens, circularam fotos das crianças, emoticons e tentativas de duas das pesquisadoras, uma professora e uma estudante, de interpretar o que as mulheres contavam. Havia uma preocupação de manter o contato ativo, ganhar confiança, deixar mais claro o que pretendíamos com a antropologia e que tipo de pesquisa estávamos a fazer e, mais importante, valorizar a troca. E assim ia transparecendo a dedicação de estar presente, ainda que virtualmente, entre essas mulheres que recentemente abriam um pouco de suas vidas à nossa equipe. Isso quis dizer, na prática, acessar o aplicativo todos os dias, ler e comentar o que nos era dito, manter uma assiduidade e presença, mas com a parcimônia necessária para não assoberbar ainda mais os cotidianos dessas cuidadoras. Como em qualquer relação de pesquisa que amadurece positivamente, fomos percebendo que laços de confiança iam paulatinamente se estabelecendo e que elas nos davam abertura para fazer e responder perguntas e, depois de algumas semanas de bate-papo virtual, para lhes propor uma visita in loco. Contando com algum recurso destinado à pesquisa de campo e estimuladas pelo progresso das conversas pelo aplicativo, ora entrevistas mais estruturadas, ora bate-papo mais fluido e cotidiano, decidimos, então, viajar até Recife. 
Por conta de limites financeiros e logísticos, somente três membros da equipe foram a Recife em outubro de 2016, no que chamamos de uma "primeira temporada de campo". As outras seis ficaram em Brasília, dando continuidade às atividades do projeto, como a organização e a realização dos grupos focais, transcrição dos arquivos de áudio, reuniões para leitura e discussão dos primeiros textos que já estavam sendo produzidos pela Antropologia e Ciências Sociais sobre a epidemia de Zika. Mas não só isso, as duas pequenas equipes, embora localizadas em cidades e regiões diferentes, não deixaram de se comunicar um só dia durante esse período da viagem.

Assim, diferentemente da tradição inicial da disciplina, esta pesquisa tem nos desafiado a organizar, planejar, realizar e discutir o pesquisar de modo coletivo. Mais do que somente a presença de várias pessoas juntas nas situações de pesquisa de campo, a relação docente-discente e também docente-docente foi uma presença constante. A pesquisa de campo foi se tornando também um importante espaço de aprendizado mútuo entre professoras e estudantes e, a distância, foi sendo acompanhada e também influenciada por quem estava em Brasília. Sabemos que a pesquisa coletiva tem crescido na Antropologia (ou talvez tenha sempre sido comum), mas notamos como pouco se fala, visibiliza e publica sobre seus resultados e desafios próprios - para excelentes relatos nesse sentido, ver Nascimento (2017) e Borges (2016). Nós também temos investido prioritariamente em formatos coletivos de trabalho nos últimos anos e nos esforçado por refletir e sistematizar tais experiências (Fleischer, 2012, 2015; Gama; Fleischer, 2016), mas a presente pesquisa nos faz refletir sobre equipes multissituadas e estratégias de comunicação remota e continuada.

\section{Virtualidades, presença, relações: A produção de um "campo estendido"}

Durante essa temporada de quinze dias de pesquisa, estivemos a todo o tempo conectadas por meio dos e-mails, telefone celular e de um grupo de WhatsApp, que foi criado pelas estudantes para o acompanhamento de todas as atividades do projeto, mas especialmente durante a viagem. Isso foi algo novo para as duas professoras coordenadoras do projeto, mas corriqueiro para as jovens pesquisadoras. Embora as professoras viessem utilizando a tecnologia em seu dia a dia pessoal e profissional, nunca a tinham aproveitado para situações de pesquisa antropológica. Detalhes tecnológicos foram, muitas vezes, ensinados pelas estudantes, numa clara relação discente-docente, desafiando o caminho mais canônico de repasse de conhecimento.

A partir do momento em que a pesquisa de campo que já acontecia em Brasília passou a também acontecer em Recife, a parte da equipe de lá contava como as coisas caminhavam e o mesmo valia para quem havia ficado. Tínhamos, ambos os grupos, tarefas semelhantes, mas a serem realizadas em locais geográficos diversos: a organização, convite e agendamento dos grupos focais com mulheres que haviam ou não sido infectadas pelo vírus Zika, que tinham ou não filhos com a síndrome congênita. E assim, as pessoas de Brasília se sentiam presentes em Recife, assim como a parte que havia ido também se presentificava em Brasília, queríamos saber dos andamentos de lá e de cá. Dificuldades e também aprendizados em uma cidade ajudavam e poupavam equívocos na outra. Avaliações das atividades eram feitas de modo diário, mútuo e continuado.

Pelo WhatsApp, várias e diferentes formas de comunicação se estabeleceram. Havia um principal grupo em que todas as estudantes e as duas professoras dialogavam, à medida que questões iam sendo colocadas ou relatos sobre as atividades da pesquisa eram feitos. Havia um grupo entre as três pesquisadoras que estavam em Recife, para conseguir resolver rapidamente os pequenos dilemas que iam surgindo ao se movimentarem e trabalharem pela cidade, por vezes juntas, por vezes em atividades independentes. Havia um grupo que reunia as pesquisadoras de campo e cada uma das mulheres que fomos, pouco a pouco, conhecendo em Recife: em cada um desses grupos, as pesquisadoras e a interlocutora marcavam as visitas e entrevistas, confirmavam endereços da cidade, informavam de atrasos, passavam os contatos (também do WhatsApp) de outras mulheres que haviam concordado em receber a equipe etc. As duas docentes também falavam entre si, numa conversa paralela e, por vezes, mais reservada, a fim de corrigir rumos, 
pensar em soluções para os problemas. Provavelmente as discentes também falavam entre si. Assim, uma presença conseguiu ser criada e mantida a partir e através da virtualidade que estabelecemos entre nós, o campo de pesquisa parecia mais ampliado e, longe de ser o estudo de gabinete, demonstrava-se como um campo poderia ser atravessado pela tecnologia, realidade virtual e presença e convivência remotas. A ideia de equipe, em que várias pessoas trabalham simultaneamente num mesmo projeto, se mantinha pelo uso do aplicativo de mensagens, mas também e-mails, telefonemas, envio de arquivos e fotos.

Vejamos alguns exemplos dessa convivência. Quando a primeira autora e as estudantes em Brasília chegaram a um grupo focal que havia sido agendado em Brasília, encontraram apenas três mulheres dispostas a dele participar. Imediatamente, a Autora 1 escreveu à Autora 2. Conversaram e juntas decidiram que, mesmo com um quórum pequeno, valia a pena realizar o grupo focal. À medida que a equipe em Recife ia visitando e conhecendo as mulheres, fomos percebendo que era comum as mães de micro pedirem que fotografássemos o encontro, para levarem uma lembrança e também deixando-a conosco. Depois da visita, a foto era enviada à entrevistada e também, como já havia sido consentido por essa mulher, era enviada à equipe de Brasília. Assim, embora parte da equipe não conhecesse essas jovens recifenses pessoalmente, ia recebendo informações que poderiam começar a ser compreendidas e discutidas como impressões de rostos, cor de pele, idade, fisionomia, figurino, contexto da casa, atmosfera do encontro etc. As primeiras reações, na forma de emoções e já insights analíticos, foram trocados nas mensagens. Fomos criando um espaço para a solidariedade acadêmica, mas também para o espontâneo, a troca, e até a emoção.

Para algumas autoras, as tecnologias intensificariam a sensação de realidade e, por isso, poderiam até ganhar mais e mais "primazia sobre outras formas de experiência corporal”, como Georges (1996) mostrou para o caso do exame de ultrassonografia no contexto grego. Esta seria uma ponta mais crítica da antropologia da ciência, sugerindo que a tecnologia apartaria as pessoas, subsumiria suas subjetividades aos objetos (Calvo-Gonzalez, 2011;
Simon, 1999). No caso de nossa pesquisa, nesse eixo Recife-Brasília, a tecnologia aproximou as equipes de pesquisa e, mais importante, humanizou a relação entre docentes, discentes e as mães e crianças da micro, muitas vezes criando relações tradicionalmente hierárquicas (por escolaridade, classe, cor, geração, por exemplo) em formatos mais horizontais e informais. Nos somamos, nesse caso, a autoras mais otimistas que, ao considerarem os usos locais dos equipamentos, percebem como novas relações podem ser criadas, como o aprofundamento do diálogo pode acontecer e até o empoderamento dos sujeitos ganha espaço (Andersen; Whyte, 2014; Bezerra; Fleischer, 2013; Storni, 2010). Ainda que a tecnologia já tenha ganhado espaço na literatura antropológica, atentando para seus diferentes usos, percebemos que ainda é pouco discutida como ferramenta e desafio éticometodológicos (Leitão; Gomes, 2013).

Partindo dessas relações paralelas ou, então, diretas, tendemos a sustentar a noção de "campo estendido", para além das ruas dos bairros de Nova Descoberta e Encruzilhada, em Recife, ou da Asa Norte ou da Ceilândia, no Distrito Federal. Por conta da tecnologia, alargamos o que se costuma denominar de "pesquisa de campo", haja vista o "campo" ter se dilatado por conta da presença-distante de suas pesquisadoras e agentes. Os processos decisórios foram partilhados pelas que estavam e não estavam, as conversas foram travadas e pesaram em escolhas e leituras de falas coletadas em uma cidade, mas analisadas a partir do que comentavam as pesquisadoras na outra cidade. Estabeleceuse um contínuo entre o Cerrado e o Nordeste. Estávamos e não "estávamos lá”, para provocar o que nos ensinou Geertz (2009), nuançando a ideia de autoridade etnográfica unicamente monopolizada pela pesquisadora (Clifford, 2011), já que conversas, informações, fotos e áudios poderiam ser circulados e comentados também pelas mulheres entrevistadas e visitadas. Aspectos notados pelas que ficaram em Brasília contribuíram para que as que estavam em Recife tivessem insights interessantes sobre o observado e vice-versa. Nesse sentido, se a pesquisa etnográfica virtual -considerando, por exemplo, websites, chats, ambientes virtuais, jogos, blogs etc. (Segata; Rifiotis, 2016) - já não é tanto uma novidade na 
Antropologia e tem mobilizado o campo teórico no que tange as suas dificuldades e facilidades (Pelucio, 2007), temos agora uma outra frente, contatos, mensagens e áudios enviados por WhatsApp. ${ }^{5}$

Mas será isso assim tão novo ou tão diferente do que acontecia entre Mead e Benedict, por exemplo, que trocaram cartas sobre suas pesquisas de campo durante muito tempo? O que há de específico em falar pelo "zap" ou no Messenger? Por um lado, os aplicativos facilitam a comunicação urgente, mantêm as pessoas conectadas simultaneamente, torna possível o "campo estendido", mas também podem contribuir para a retração das pessoas, a permanência cômoda na virtualidade e a ausência de presença física. Uma das pesquisadoras que estava em Recife, por exemplo, teve muita dificuldade de telefonar para uma das mulheres que seria entrevistada, sentindo-se tímida ou despreparada. Ou, a pesquisadora teclar com outra que está em Brasília pode contribuir à desconcentração ou evasão da cena que se passa diante dos próprios olhos, ali no bairro visitado em Recife ou durante um grupo focal realizado na Ceilândia/DF. Ou ainda, mesmo que a pesquisadora esteja anotando no bloco de notas do celular, funcionando assim como uma espécie de caderno de campo, ela pode parecer estar falando no WhatsApp com outra pessoa longe dali, dando a impressão à interlocutora de falta de atenção e cuidado com a entrevista. Desse modo, o "zap" nos coloca em "contato com", mas talvez nos priva de perceber os corpos, os gestos e trejeitos faciais, as lágrimas, os sorrisos e o suor que tanto também podem nos dizer sobre o que Malinowski ([1922]1976) entendia como o corpo, o esqueleto e, sobretudo, o espírito e os imponderáveis, ou "o que pensam sobre o que fazem os nativos?", "o que dizem que fazem os nativos?" e "o que efetivamente fazem os nativos?" (Geertz, 2001).

Desse modo, em nossa leitura, o "campo estendido" seria o ambiente etnográfico do encontro virtual e presencial, que, no entanto, borra tais noções, pluralizando agentes de pesquisa, a relação com as interlocutoras e a noção de diálogo. 0 "campo estendido" enquanto ambiente com múltiplos atores, aqui e lá - e tudo que há no meio disso, pode ser muito útil nos processos de estranhamento do vivido. Por isso, talvez as observações das pesquisadoras que não estavam na cidade onde a pesquisa acontecia tenham sido tão úteis para facetas do que lá acontecia e como acontecia, por meio de imagens, perguntas ou comentários sobre s próprias mensagens.

No limite, o “campo estendido" parece ter também uma dimensão relacional, aspecto observado por Lira, Scott e Meira (2017) em artigo que discute a prática da pesquisa em equipe, os corpos e os afetos em campo também no universo materno atravessado pela SCZV. Segundo as autoras, o corpo da pesquisadora que carrega o bebê com microcefalia nos braços sente um pouco do que a mãe sente, um peso físico, mas também emocional - quando uma das pesquisadoras acompanha a crise de Daniel em seu colo (Lira; Scott; Meira, 2017, p.231). Para as antropólogas, carregar o bebê como a mãe o carrega, ainda que por pouco tempo, afetaria esse corpo de modo a sentir na pele o que vivem essas mães (Fleischer, 2017). Os seus corpos, então, tornam-se relacionais, um tipo de "corpo estendido", analogamente ao que temos pensado aqui por "campo estendido", haja vista o campo conectar e relacionar pesquisadoras lá e cá e, assim, ser reconfigurado continuamente. Há, então, nessa ideia de campo estendido, antes ou a priori, a relacionalidade dos espaços e entre as pessoas. Em nosso caso, entre as pesquisadoras que ficaram e as que foram. Mas também entre as que ficaram aqui e as mães de micro de lá.

\section{Impactos da pesquisa coletiva sobre as mães, crianças e famílias de micro}

Se o recente artigo de Lira, Scott e Meira (2017) pondera, de modo geral, sobre os impactos da ciência sobre essas interlocutoras em Recife, incluindo as iniciativas vindas da Antropologia, aqui, tomamos sua contribuição como norte, mas concentramos especificamente nos efeitos que a pesquisa realizada coletivamente pode gerar sobre as mulheres participantes.

\footnotetext{
5 Percebemos que há um conjunto de nuances, mais ou menos complicadas em termos ético-metodológicos, a respeito do uso do WhatsApp como ferramenta de pesquisa na Antropologia. Embora o aplicativo esteja cada vez mais presente nas pesquisas da área, ainda precisamos de mais reflexão sobre ele (FLEISCHER, S. Zapzap no cenário da microcefalia: oportunidades para pensarmos sobre cuidado, tecnologia e antropologia. No prelo).
} 
A partir das duas que responderam nosso convite por carta postal, conhecemos cerca de outras dez mulheres. Nessa primeira temporada de campo, ainda em 2016, visitamos todas elas, ao menos uma vez, e as reencontramos em outras ocasiões, nas atividades terapêuticas e nos encontros nas ONGs que têm apoiado as vítimas da epidemia. O desenho metodológico desse projeto pretende reencontrá-las a cada vez que se visita Recife. Nesse quadro, essas mulheres foram expostas a uma grande rotatividade de pesquisadoras de nosso projeto, já que, desde então, apenas a segunda autora deste artigo, na figura de docente e coordenadora da pesquisa, esteve todas as vezes nas viagens. Embora essas mães tenham tido a chance de conhecer muitas pessoas, é comum perguntarem como vão as duas estudantes que estiveram na primeira temporada. Elas são as pesquisadoras que essas mulheres identificam principalmente como "trabalhando com a Autora 2".

Embora as pesquisadoras visitantes sejam sempre apresentadas pela referida professora e se beneficiem da relação mais duradoura realizada pela nossa equipe, reconhecemos que o vínculo de confiança e a sensação de continuidade, aspectos tão centrais às pesquisas da Antropologia, pode ser algo mais difícil de consolidar com essa rotatividade. Assim, por mais que o projeto se proponha a revisitar e conviver com as mesmas mulheres ao longo de um longo período (abordagem diacrônica mais do que sincrônica), esse intuito de acompanhamento talvez fique mais claro para a docente do que para qualquer outra parte, seja interlocutora, seja estudante. Gostaríamos de ser vistas pelas mães de micro como o "mesmo pessoal de Brasília" e mais e mais sentimos que essa alcunha tem se consolidado. Porém, ao propor que o trabalho seja realizado em grupo, talvez estejamos lhes exigindo um constante esforço de aceitação, acomodação e adaptação a várias pessoas que por ali chegam para visitar e conversar. Uma certa maleabilidade por parte das mães parece ser exigida nesse formato coletivo de pesquisar.

Por outro lado, é possível apostar que essas mulheres tenham a sensação de terem conhecido muita "gente de Brasília", e isso pode ser um elemento positivo para quem, frequentemente, precisa estar na capital federal para atividades de advocacy no Ministério da Saúde ou no Congresso
Nacional. Também é preciso considerar que, como discutimos acima, a virtualidade perpassa também a relação com elas. Notamos como, mesmo após nossa partida de Recife, continuamos em diálogos pelo WhatsApp e pelo Facebook. Elas nos contam, cada vez mais espontaneamente, como se desenrolaram fatos e situações que vimos começar quando lá estivemos. Vamos nos atualizando mutuamente, apostando que a ausência física não significa uma ausência completa. Elas nos acionam para participar de vakinhas virtuais (para comprar equipamentos e medicamentos para as crianças). Enviam fotos das crianças, marcam nosso perfis em eventos que estejam divulgando no Facebook, puxam papo no Messenger, têm a chance de saber também de nossas vidas de volta à Brasília, com nossas estudantes, filhos e famílias.

Esses são todos meios de comunicação usados com maestria pelas estudantes e, pela proximidade etária, apostamos que essas recifenses tenham mais facilidade de receber e interagir com as estudantes brasilienses. Mas também percebemos como o formato coletivo pode produzir algum tipo de assoberbamento, no sentido de se traduzir na forma, por exemplo, de mais perguntas, mais olhos, as salas das casas pequenas ficam mais cheias e apertadas, mais gastos para oferecer café e lanche durante uma visita. A trupe que acompanha pelas ruas se torna mais volumosa e visível, nossa presença dentro dos hospitais e clínicas de reabilitação demandam mais esforços de negociação para acomodar esse grupo maior. Como a cada temporada é uma pesquisadora em formação que vai, dúvidas iniciais podem ser dirigidas às mães de micro, numa repetição enfadonha, a partir de uma pauta que não lhes é tão prioritária naquele momento. E, por isso, temos insistido que a formação básica para viajar a Recife é ler os tomos de diários de campo produzidos pelas equipes anteriores num esforço de atualização e, mais do que tudo, atenção para os temas e questões que as mulheres tenham nos apresentado. Mas sabemos que há sempre inexperiência e desconhecimento na primeira incursão ao campo e é nessa convivência com as mulheres recifenses que a formação como pesquisadora está acontecendo. Nesse sentido, as novatas somavam-se e criavam estratégias próprias de inserção em um campo já iniciado. É preciso, como 
docentes, estarmos atentas para o quanto as mães de micro estão sendo demandadas a atuarem nesse papel de docentes informais dessas pesquisadoras neófitas e se, de fato, desejam mais essa tarefa no seu rol de atribuições e responsabilidades diárias de cuidado com uma criança com deficiência. Esses encontros nos provocam a pensar em formatos de coordenação e docência compartilhadas com elas inclusive em termos de reconhecimento e autoria - e, ao mesmo tempo, em evitar que a pesquisa coletiva lhes gere ainda mais assoberbamento.

\section{O "estar aqui" e os diários partilhados: construção coletiva da ética em pesquisa}

Diários de campo foram produzidos individualmente e depois compilados em um só arquivo, impresso e debatido no grupo, entre as que ficaram e as que lá estiveram, quando todo mundo já estava reunido de volta em Brasília. O resultado publicizado, como sempre alertamos ao grupo, deveria ser uma versão editada do diário de campo, em que tivessem sido retiradas todas as menções e alusões que, por ventura, pudessem constranger qualquer parte envolvida, seja autora, interlocutora ou leitora. Essa cautela ética visava manter a primeira versão escrita do diário de campo como espaço, por excelência, de liberdade e desabafo para a autora, mas que ainda pudesse servir e circular como um material coletivo de pesquisa. Ao todo, foram produzidas 212 páginas, com impressões de três antropólogas que estiveram em Recife nessa viagem de 2016. Mas o material foi analisado por um grupo maior, com as outras seis pesquisadoras. Passamos semanas debruçadas sobre os escritos, a cada encontro discutindo o conjunto de diários relativos a um dia de campo, ouvindo-nos umas às outras a partir do que a escrita nos suscitava.

Para nós, docentes, funcionou como uma oportunidade, a um só tempo, de ensinar a fazer trabalho de campo e a escrever o diário como seu resultado. Em geral, o diário é uma peça pouco conhecida, ensinada e compreendida. Por isso, ler, comentar e escutar a antropóloga que o escreveu funcionou com uma oportunidade única de ensino e de aprendizagem. Para quem escreveu e para quem leu, essas reuniões nos aproximaram umas das outras. Os relatos de campo nos informaram, nos emocionaram, nos enfureceram, nos trouxeram alguns segredos que ali foram deliberadamente partilhados e guardados e também nos ensinaram como fazer circular os nossos diários de campo, por vezes também pessoais.

Ao ser compartilhado, um diário revela como uma cena foi apresentada e descrita pela autora, tem sua capacidade comunicativa, alusiva e imaginativa testada pela leitora. Fica mais claro se esse trecho precisa de complementação, se está gerando malentendidos e ruídos, se consegue sugerir conexões entre diferentes trechos do material, por exemplo. A autora pode retomá-lo, incluindo frases ou novas elaborações para que fique mais claro, incorporando detalhes que lhe escaparam da memória na primeira redação, alargando os entendimentos sobre sua relação com as interlocutoras em campo, tomando consciência dos limites de sua observação. Também contribui para que aquela pesquisadora que não foi a campo dessa vez e/ou que nunca antes tivesse escrito um diário de campo já pudesse ir acumulando práticas de observação, descrição, registro, ampliando cada vez mais seus repertórios de pesquisa. Essa pesquisadora já iria para Recife, de uma próxima vez, um pouco menos insegura, conseguindo vislumbrar um pouco melhor como é a cidade e suas redes de transporte, como é a vida de uma mãe e filha de micro e que vozes, versões e agentes estão aí presentes, quanto tempo se precisa para relatar sobre um dia passado em campo, que tipo de elementos precisam ser considerados ao produzir um diário sobre esse dia etc.

Justamente por isso, pensamos, que o modus operandi de nossa pesquisa tencionou também a autoria dos diários do campo. Não que tenham se tornado necessária ou totalmente textos coletivos. Mas puderam ser analisados a partir de muitas cabeças e corações, mostrando-nos o quanto pode ser interessante pensar coletivamente. Muito do que uma ouve, ecoa de outro modo na outra, tanto a fala quanto a escrita. A ideia não era fazer da pesquisa um laboratório de escrita etnográfica e tampouco uma reedição de uma disciplina de técnicas e métodos antropológicos, mas acabou funcionando também 
nesses sentidos. E, embora não tenhamos, nesse momento, total clareza sobre esse ponto, é possível apostar que a leitura desses diários de campo tenha influenciado muito a forma de observar, lembrar e escrever das pesquisadoras que posteriormente seguiram a Recife nas viagens subsequentes (20172019). Assim, visto individualmente, o diário tem claramente uma autoria individual, mas tomado como um material mais contínuo e inteiro, os conjuntos de diários foram se tornando material coletivamente utilizado e produzido. Para nós, docentes, foi rico e também pedagógico vermos umas às outras nesse processo de construção dos diários das pesquisadoras-alunas e em como ensinamos o fazer etnográfico. Trocamos entre nós, estratégias de prática e de ensino.

Muitas vezes escrever um diário de campo pode parecer uma tarefa misteriosa, quase uma incógnita porque pouco lemos diários alheios, pouco os tomamos como uma peça também construída socialmente. Há poucos diários de campo publicados e poucas são as antropólogas dispostas a compartilhar seus diários de campo como uma publicação oficial. ${ }^{6}$ Há um entendimento de que esse é um tipo de texto idiossincrático, no qual não cabe ensinar como construí-lo, já que dependerá do campo, das pessoas conhecidas aí, da autora que registra esses encontros. Há um entendimento na área de que, natural ou espontaneamente, a antropóloga saberá como produzir seu diário de campo, quando o momento assim demandar. Nesse projeto, aos poucos, fomos revendo esse status quo da área, experimentando escrever e também entender quais eram as possibilidades que tínhamos à mão para produzir, ler, compreender esse tipo tão específico de material de pesquisa.

Dessa forma, oferecer ao diário concretude, debate e devolutiva funcionou como um grande salto pedagógico. Víamos como a mesma situação podia ser narrada de modos diversos por quem a vivia. Notamos maneiras mais sintéticas, maneiras mais detalhadas. Deparamo-nos com os desafios da escrita para algumas, com a facilidade para outras. Percebemos cenas que escalaram em intensidade emocional e as soluções narrativas que cada pesquisadora encontrou para ali permanecer presencialmente e depois para no diário descrever remotamente, implicando-se mais ou menos na cena, retendo mais ou menos essa intensidade, deixando entrever ou não sua própria reação psíquica e/ou afetiva com tudo aquilo. E assim experimentamos as dificuldades de concentração para escrever e de dedicação de tempo necessário para executar tal tarefa.

Também aprendemos sobre o compromisso ético com a partilha desse material. Os diários circularam no grupo, mas dali não poderiam sair. Eles foram disponibilizados na versão impressa e encadernada em papel e também como arquivos eletrônicos, enviados por e-mail à equipe e mantidos em uma nuvem específica da pesquisa. Independentemente do suporte, os diários não poderiam ser passados adiante para outras pessoas que não estivessem dentro da equipe. Era necessário o cuidado com as histórias que não haviam sido coletadas ou vividas por toda a equipe, mas que, sabidamente, seriam por todas nós partilhadas. Repassar os diários poderia gerar o risco de essas histórias ficarem sem contexto, serem mal interpretadas, vulnerabilizar ainda mais essas mulheres que íamos conhecendo em Recife. $\mathrm{O}$ pacto que as pesquisadoras de campo haviam firmado com suas interlocutoras precisava ser mantido por todas as pesquisadoras, inclusive aquelas que tiveram acesso apenas ao material escrito. E aqui estamos falando dos desafios específicos que uma pesquisa coletiva apresenta, já que exige que etapas diferentes e sucessivas de consentimento sejam percebidas e repactuadas, agora com autoras que nem sequer estiveram face a face com as interlocutoras iniciais.

De mesmo modo, era necessário o compromisso com a indicação de autoria da pesquisadora que havia produzido aquele diário, caso outra colega desejasse citá-lo em algo que estivesse escrevendo. ${ }^{7}$ Os frutos de nossas reflexões eram coletivos e assim sugeríamos que também fossem registradas quando estivéssemos escrevendo os TCCs, artigos de ICs, papers a serem apresentados em congressos, ensaios de final de disciplina etc. Na prática, todas

\footnotetext{
6 Para exemplos de alguns diários de campo que foram publicados, ver Ribeiro (1979), Cesara (1982) e, para uma discussão sobre esse tipo de material, a Introdução de Bonetti e Fleischer (2007)

7 Valim (2017) é um bom exemplo de como esse cuidado ético foi realizado na prática.
} 
nós deveríamos cuidadosamente citar o diário de campo e sua autora, em vez de realizar paráfrases sem aspas ou sem autoria. Aqui, o pleito não era por individualizar a produção intelectual ao extremo, o que talvez possa parecer um contrassenso diante da proposta de trabalho coletivo, mas garantir a transparência da produção do conhecimento. Uma solução que muitas de nós adotamos foi escrever e assinar os textos a quatro, seis ou muitas mãos.

Nesse grupo de pesquisa, como já mencionamos, contávamos com estudantes de graduação em antropologia e em saúde coletiva, aos quais interessa, em nossa leitura, em igual peso a reflexão sobre a prática da pesquisa qualitativa, de uma pesquisa social e/ou de uma pesquisa etnográfica. Sabe-se como a metodologia de pesquisa qualitativa importa muito para o campo da saúde, haja vista debruçar-se sobre os significados que as pessoas oferecem às pesquisas de saúde/doença, em sua compreensão profunda e situada. Justamente por isso, o modus operandi de uma pesquisa social coletiva em saúde, mais corriqueira nas ciências da saúde, importa tanto para antropologia quanto para a saúde coletiva. Mesmo porque a antropologia contribui decisivamente para o campo da saúde coletiva, desde o seu surgimento, nos idos de 1980, compondo o campo anunciado como Ciências Sociais em Saúde. O seu modo de pesquisar, de etnografar e, assim, a raiz de sua própria existência é fundamental para o campo das práticas e saberes em saúde, foco da saúde coletiva. Diante disso, as discussões travadas ao longo de todo o artigo nos parecem fundamentais a ambos os campos, quando dedicados ao estudo de assuntos que compõem o grande campo da saúde, como é o nosso caso.

\section{Docente, pesquisadora e coordenadora: A atuação triplice da antropóloga}

Nas conversas, visitas e circulações em Recife, nos grupos focais de Brasília, nós duas erámos, a um só tempo: (1) pesquisadoras; (2) docentes; e (3) coordenadoras do projeto de pesquisa. Estávamos em uma tripla jornada ou três papéis sociais simultâneos. Esse pertencimento múltiplo nos pedia mais atenção do que aquele em que comumente estamos fazendo tudo isso solitariamente e tornou-se um exercício interessante para pensarmos.

A Autora 2 conta que, na casa de uma das mulheres em Recife, enquanto segurava a criança em seus braços, sentiu a necessidade de que uma das alunas sacasse o seu caderno de campo e anotasse o que aquela mulher lhes contava de precioso, mas não podia fazer isso, sem interromper a cena em que a mulher falava, uma pesquisadora mais jovem sustentava a conversa com a mãe, a outra brincava com filho mais velho e a criança era embalada pela professora. Mesmo que, naquele momento, a Autora 2 estivesse presente como seus olhos e ouvidos de pesquisadora, não conseguiu comunicar plenamente seu papel docente. De mesmo modo, em seus diários de campo, relatou as dificuldades de coordenar a escrita das alunas-pesquisadoras e do quanto essa tarefa ia ficando atrasada. As atividades de pesquisa ocupavam muitas horas do dia e continham graus variados de dificuldade e densidade etnográfica. Ora eram encontros espalhados geograficamente, exigindo que a cidade fosse mapeada e compreendida, que o deslocamento fosse cumprido, que a mudança de atmosfera fosse acomodada (de uma casa à uma instituição, por exemplo; de uma conversa íntima com uma pessoa para um animado bate-papo com várias delas etc.). Ora eram conversas, no espaço doméstico ou público, muito densas e longas, exigindo que emoção, memória, linearidade das ideias fossem retidos. Ora eram circunstâncias mais politizadas e coletivas, em que discussões estavam em curso, discursos vinham sobrepostos, tensões e posições estavam no ar, mas precisavam ser percebidas e captadas. Esses diferentes cenários exigiam que as pesquisadoras dedicassem muitas horas, ao final do dia, de noite ou de madrugada, para que o diário fosse escrito em sua integridade. Nos primeiros dias em Recife, a docente percebeu que as estudantes estavam voltando a campo sem que o diário do dia anterior estivesse terminado, facilitando com que ideias e percepções se confundissem ou, pior, se perdessem. Assim, as duas docentes deliberaram e decidiram trocar um "dia de rua" por um "dia no gabinete", com o objetivo de terminar os diários de campo que estavam incompletos e/ou atrasados. Claro, aqui se sacrifica o privilégio de estar numa outra cidade, em contato 
direto com as interlocutoras que fomos conhecer e visitar. Perde-se, portanto, tempo convivendo com elas, mas ganha-se na qualidade do registro, material que servirá àquela pesquisadora imediatamente e também às futuras equipes que integrassem a pesquisa, ganhando vida, posteridade e rendimento.

Nas linhas de seus diários, vemos como, a um só tempo, a pesquisadora com os seus insights, seus contatos de campo e suas interpretações; a coordenadora da pesquisa, em contato estreito com sua colega, tentando resolver problemas e encontrar soluções; e a professora, querendo deixar ensinamentos sobre como realizar a pesquisa, escrever um diário de campo consistente e apresentar, assim, uma oportunidade que poucas estudantes de graduação possuem atualmente de aprender de modo concreto e acompanhado. De mesmo modo, nos tempos de certa forma "livres" ou "intervalares", em que estavam transitando dentro dos ônibus, fazendo a refeição do café da manhã na casa em que ficaram hospedadas ou no saguão do aeroporto esperando pelo embarque, ela aproveitava para instigar as estudantes a refletir sobre os acontecimentos que haviam vivenciado, no sentido de: (1) terem clareza do que haviam visto e de como o comunicariam no diário; (2) tomarem a frente da própria pesquisa, adotando atitudes individuais como ligar ou, como preferiam, escrever por WhatsApp para agendar uma entrevista ou acompanhar uma mulher e seu filho que somente ela tivesse conhecido na sala de espera de uma clínica; (3) seguir pistas ou intuições que a estudante pudesse ter tido, mesmo que destoassem da interpretação da professora ou da outra colega pesquisadora. Assim, ao nos situar em uma pesquisa coletiva, vamos borrando as fronteiras entre "dia de rua" e "dia de gabinete", já que em ambos os espaços de ensinamentos e de aprendizados podem acontecer, mesmo que com intensidades e sinestesidades diferentes.

De mesmo modo, ainda que em escala menor, Autora 1 também sentiu essa tripla atuação nos grupos focais e reuniões que aconteceram em Brasília. Era preciso ensinar a conduzir o grupo focal, direcionar as questões, não deixar a participantes do grupo se perderem da linha de discussão e, ao mesmo tempo, se desprender do debate, observar como as pesquisadoras e pesquisadas conviviam, perceber o seu envolvimento e o seu desenvolvimento.
Mas, ao mesmo tempo, as respostas às questões e os debates suscitados faziam a docente refletir sobre a relação entre vacinas e Zika vírus na gestação, de modo a ponderar sobre a pesquisa mais ampla. É muito diferente de orientar um trabalho de investigação à distância, quando somos apenas as leitoras dos resultados escritos da pesquisa. É muito diferente de sabermos sobre o campo da estudantepesquisadora apenas pelos seus relatos posteriores. E é muito diferente de quando somos somente nós em campo, por nossa conta. Pois, no caso que aqui apresentamos, vemos o que se passa, pensamos sobre a prática das estudantes e ocupamos, ao mesmo tempo, três lugares diferentes. A professora, a pesquisadora e a coordenadora estão ali, presencial e virtualmente também. E a um só tempo em um campo estendido de relações sociais.

Peirano (2008) nos diz que é impossível ensinar o passo a passo da etnografia, pois dela dependerá a bagagem pessoal das pesquisadoras. Mas ainda assim estamos convencidas de que exercícios como esses, propostos em nossa pesquisa coletiva, podem ajudar muito a prática de pesquisa de quem começa na graduação, pois se pode ver as outras colegas em campo, observar traquejos, desafios e possibilidades de superação de algum obstáculo para a pesquisa. Ademais, aprende-se concretamente, vendo, ouvindo e escrevendo, individual e conjuntamente.

De nossa parte, autoras deste artigo, pensamos ser esse um tema para desdobramentos futuros e de maneira aprofundada. Quais são os limites desses tantos pertencimentos? Como nos posicionamos e quais seriam as saias justas enfrentadas por nós, enquanto pesquisadoras, docentes e coordenadoras, com tripla existência em campo? Que tipo de Antropologia é possível em conjunturas coletivas como essas?

\section{A pesquisa antropológica depois da maternidade: experiência compartilhada, estranhamentos $e$ dilacerações}

O compilado dos diários de campo relativo a essa primeira temporada de pesquisa tem início com a descrição feita pela Autora 2, ainda em casa, 
arrumando as malas para a viagem a Recife. Um dia antes da viagem, efetivamente. Na cena, estavam ela e sua filha de seis anos à época. A pequena vê uma foto de um bebê com microcefalia e não reconhece na criança a cabeça pequena como um possível problema. A antropóloga se surpreende com a negação da menina diante daquilo que mais parece chamar a atenção dos demais. Mas segue para campo com essa leitura em mente (Fleischer, 2017). Afinal, o que seria e como seria vista e vivida a microcefalia pelas mães que, finalmente, conheceria pessoalmente na outra cidade? De uma mirada infantil, como irmãos e outras crianças percebem a microcefalia e a epidemia?

Em outros trechos do diário dessa pesquisadora, professora e mãe aparecem os relatos de saudade da filha que ficara em Brasília. "Não dá mais para ficar tantos dias longe de casa. Fico com muita saudade de minha filha". A Autora 1, ao ser convidada para compor o grupo de pesquisa, ainda naquele início do projeto e da epidemia, a princípio, pensou em negar. Mas depois condicionou as viagens a Recife somente mais para a frente, já que estava com filho de pouco mais de um ano à época.

Éramos mães com crianças pequenas fazendo pesquisa sobre mães de crianças pequenas. Nesse sentido, nossa identificação, mas também diferença de contexto materno, desenhou a nossa inserção em campo. Em alguns trechos dos seus diários de campo, a Autora 2 se recorda de sua filha pequena e sente mais familiaridade para segurar uma criança, para ter maior desenvoltura em cena com as mulheres, por conta de já ser mãe. Comparava a si mesma com suas estudantes, todas solteiras e nulíparas à época. Em outro sentido, entretanto, faz com que olhemos para o cotidiano dessas mulheres recifenses e pensemos sobre o "cansaço", sobre "amor de mãe", sobre "cuidado", com olhos de mães, tanto para estranhar quanto para aproximar (Velho, 1978), sempre levando em conta a complexidade da presença de uma criança com deficiência. Muitas foram as vezes em que visitas e entrevistas tiveram que ser remarcadas porque essas crianças pequenas adoeciam ou também ficavam cansadas de zanzar pela cidade. Em nossos encontros em Recife, as necessidades desses bebês precisaram ser atendidas e as pesquisadoras foram, em geral, convidadas a ajudar, seja amparando uma bolsa enquanto algo era ali dentro buscado pela mãe, seja atendendo a criança enquanto a mãe resolvia outro assunto na clínica ou no transporte, por exemplo. Impossível deixar de notar e anotar todas essas passagens nos diários de campo, permeados, assim, pela nossa condição de maternidade. Somos mães, mas mães de camadas médias a pensar sobre o cuidado praticado por mulheres de periferia, no contexto da deficiência e de uma epidemia em processo de explicação. E assim, em alguns pontos, nos aproximamos; em outros, claramente nos diferenciamos. Outra equipe de antropólogas-mães, também trabalhando com as mães de micro em Recife (Lira; Scott; Meira, 2017), discutiu, especificamente, como a experiência de maternidade e de deficiência, compartilhada entre pesquisadoras e interlocutoras, provocou também situações ambivalentes, mas demonstraram sensibilidade e habilidade para atravessarem -juntasos abismos que esses encontros com a alteridade lhes apresentaram.

Sendo assim, nossa existência em campo já tão estendida e com tantas fronteiras borradas, torna-se um pouco mais ampla. Somos docentes, pesquisadoras e mães de crianças pequenas. Essas seriam as nossas marcas e limites de compreensão do universo analisado. Mas aqui gostaríamos de pensar sobre a dimensão metodológica e prática dessa prática etnográfica. Como fazer pesquisa de campo com crianças pequenas? Como deixar nossas casas, com quem ficam os nossos filhos? Ou os levamos conosco? Quais os impactos disso em campo, que tipo de pesquisadoras conseguimos ser se nossos filhos estão distantes a nos provocar uma sensação de ambiguidade, incompletude e saudade, ou que tanto de tempo se abre quando estamos desincumbidas das atribuições maternas e domésticas, podendo nos dedicar mais longamente a conviver e escrever com as nossas companheiras - interlocutoras e também estudantes - em campo?

Recentemente, foi divulgada uma imagem de Marilyn Strathern com seus dois filhos em campo, em 1976, feita por Paula Brow, entre os Hagen. ${ }^{8}$ Na imagem, vemos Strathern com uma das crianças nos 
braços e a outra no colo de um homem Hagen. Circulou também, faz pouco tempo, a notícia de uma mesa redonda na Cultural Anthropology "Mother Antihero, a Roundtable: Reports from a 21st Century Field". ${ }^{9}$ Sinais de que o assunto tem atravessado a Antropologia mais amplamente e parece adquirir outros contornos nesse começo de século. No limite, há que se pensar: Como fica a pesquisa de campo e o olhar das antropólogas mães de crianças ainda pequenas? Quais são os limites e as particularidades que enriquecem esse olhar? 0 quanto a experiência comum de filhos pequenos abre ou fecha possibilidades de interlocução em um campo sobre maternidade, infância e deficiência, como encontramos em Recife e em Brasília? Eis pontos para pensarmos ainda mais. Em nosso caso, funcionou com espelho, como lente de compreensão do que ocorria, como solidariedade, mas também estranhamento, distanciamento e motivo de perplexidade, tudo contribuindo para gerar novas reflexões.

\section{Considerações finais}

Com esse artigo procuramos, então, pensar sobre o que o modus operandi de uma pesquisa coletiva pode gerar à prática etnográfica contemporânea em saúde. Uma pesquisa coletiva e atravessada pela tecnologia, que deslocou pessoas e papéis sociais ao longo do tempo e do espaço. Nesse sentido, Lira, Scott e Meira (2017, p. 233) nos inspiram, ao mesmo tempo que sintetizam alguns dos aprendizados de nossa equipe:

Quando etnógrafos relatam as emoções que afetaram as suas vidas durante e posteriormente a suas experiências em campo, o que se enxerga prioritariamente é uma experiência individualizada. Trabalhando em equipe isso pode primeiro aparecer como uma pressão para a cientificação despersonalizante da experiência, mas no compartilhamento de informações e percepções de forma regular a equipe experimenta essa vivência como uma ampliação da sensibilidade coletiva, que enriquece a possibilidade de estar mais consciente do impacto da sua presença "nas cuidadorascrianças”, nas mães de micro e seus filhos e filhas.
Pensando, assim, não somente a nossa relação com a tecnologia, mas também os efeitos sobre a pesquisa a partir de afetos, gerações, classes sociais, gênero, filhos e as particularidades de uma investigação coletiva. Também consideramos uma ideia de campo estendido e feminino, orientada por duas antropólogas mães de crianças pequenas e em relação direta com interlocutoras, estudantes e colegas acadêmicas. Pretendemos discutir isso tudo com a objetivo de pensar sobre a etnografia, a docência e a pesquisa em saúde que estão sendo produzidas neste início do século XXI, provocandonos a produzir novas reflexões, novos avanços no diálogo coletivo e interdisciplinar.

\section{Referências}

ANDERSEN, J. H.; WHYTE, S. R. Measuring risk, managing values: health technology and subjectivity in Denmark. Anthropology \& Medicine, Abingdon, v. 21, n. 3, p. 265-276, 2014.

BENEDICT, R. Padrões de cultura. Trad. Alberto Candeias. Lisboa: Livros do Brasil, 2000.

BEZERRA, N.; FLEISCHER, S. A popularização de esfigmomanômetros e glicosímetros no bairro da Guariroba, Ceilândia/DF. Sociedade e Cultura, Goiânia, v. 16, n. 1, p. 183-193, 2013.

BONETTI, A.; FLEISCHER, S. Introdução. In: BONETTI, A.; FLEISCHER, S. Entre saias justas e jogos de cintura. Florianópolis: Editora Mulheres; Santa Cruz do Sul: Edunisc, 2007. p. 9-40.

BORGES, A. República das mangas ou sobre o amargo gosto de tudo o que amadurece à força. REPOCS, São Luís, v. 13, n. 25, p. 21-42, 2016.

BRASIL. Ministério da Saúde. Secretária de Vigilância em Saúde. Monitoramento integrado de alterações no crescimento e desenvolvimento relacionadas à infecção pelo vírus Zika e outras etiologias infecciosas, até a Semana Epidemiológica 52 de 2018. Boletim epidemiológico, Brasília, DF, v. 5o, n. 8, p. 1-8, 2019.

CALVO-GONZALEZ, E. Construindo corpos nas consultas médicas: uma etnografia sobre 
hipertensão arterial em Salvador, Bahia. Cadernos CRH, Salvador, v. 24, n. 61, p. 81-96, 2011.

CESARA, M. Reflections of a woman

anthropologist: no hiding place. Philadelphia:

Temple University Press, 1982.

CLASTRES, P. Sociedade contra o Estado:

pesquisas de antropologia política. Rio de Janeiro:

Francisco Alves, 1986.

CLIFFORD, J. Sobre a autoridade etnográfica.

In: CLIFFORD, J. A experiência etnográfica:

antropologia e literatura no século XX. Rio de

Janeiro: Editora da UFRJ, 2011.

DINIZ, D. Zika: do sertão nordestino à ameaça global. Rio de Janeiro: Civilização Brasileira, 2016.

EVANS-PRITCHARD, E. Os Nuer. São Paulo: Perspectiva, [1940]1978.

FLEISCHER, S. Atenção básica de saúde, cronicidade e Ceilândia: $\mathrm{O}$ que tudo isso tem a ver com o ensino da Antropologia? Percursos, Florianópolis, v. 13, p. 23-39, 2012.

FLEISCHER, S. Segurar, caminhar e falar. Notas etnográficas sobre a experiência de uma mãe de micro no Recife/PE e a antropologia feita em casa. Cadernos de Gênero e Diversidade, Salvador, v. 3 , n. 2, p. 93-112, 2017.

GAMA, F.; FLEISCHER, S. Na cozinha da pesquisa: relato de experiência na disciplina Métodos e Técnicas em Antropologia Social. Cadernos de Arte e Antropologia, Salvador, v. 5, p. 109-127, 2016.

GEERTZ, C. Obras e vidas. O antropólogo como autor. Rio de Janeiro: Editora da UFRJ, 2009.

GEORGES, E. Fetal ultrasound imaging and the production of authoritative knowledge in Greece. Medical Anthropology Quarterly Washington, DC, v. 10, n. 2, p. 157-175, 1996.

LEITÃO, D. K.; GOMES, L. G. Estar e não estar lá, eis a questão: pesquisa etnográfica no Second Life. Cronos, Natal, v. 12, n. 2, p. 23-38, 2013.

LIRA, L. Mães de micro: três redes de cuidado e apoio no contexto do surto da síndrome congênita do vírus zika no Recife - PE. 2017. 90 f. Monografia (Graduação em Antropologia)
- Departamento de Antropologia, Instituto de Ciências Sociais, Universidade de Brasília, Brasília, DF, 2017.

LIRA, L. C.; SCOTT, R. P.; MEIRA, F. Trocas, gênero, assimetrias e alinhamentos: experiência etnográfica com mães e crianças com síndrome congênita do Zika. Anthropológicas, Recife, v. 28, n. 2, p. 206-237, 2017.

MALINOWSKI, B. Argonautas do Pacífico Ocidental. São Paulo: Abril Cultural, [1922]1976.

MEAD, M. Sexo e temperamento. São Paulo: Perspectiva, [1935]1969.

NASCIMENTO, S. Entrevista: a pesquisa coletiva. Mandaú, Maceió, n. 3, p. 202-211, 2017.

PEIRANO, M. Etnografia ou a teoria vivida. Revista Ponto Urbe, São Paulo, v. 2, n. 2, p. 1-10, 2008.

PELUCIO, L. No salto: trilhas e percalços de uma etnografia entre travestis que se prostituem. In: BONETTI, A.; FLEISCHER, S. (Org.). Entre saias justas e jogos de cintura. Florianópolis: Editora Mulheres; Santa Cruz do Sul: Edunisc, 2007. p. 93-124.

PEREIRA, E. et al. Perfil da demanda e dos benefícios de prestação continuada concedidos a crianças com diagnóstico de microcefalia no Brasil. Ciência e Saúde Coletiva, Rio de Janeiro, v. 22, n. 11, p. 3494, 2017.

PLOURDE, A.; BLOCH, E. A literature review of Zika virus. Emerging Infectious Diseases, Atlanta, v. 22, n. 7, p. 1185-1192, 2016.

PORTO, R.; COSTA, P. R. S. M. O corpo marcado: a construção do discurso midiático sobre Zika vírus e microcefalia. Cadernos de Gênero e Diversidade, Salvador, v. 3, n. 2, p. 158-19o, 2017.

RIBEIRO, B. G. Diário do Xingu. Rio de Janeiro: Paz e Terra, 1979.

SEGATTA, J.; RIFIOTIS, T. (Org). Políticas etnográficas no campo da cibercultura. Brasília, DF: ABA Publicações; Joinville: Letradágua, 2016.

SIMON, C. M. Images and image: technology and the social politics of revealing disorder in a North American hospital. Medical Anthropology Quarterly, Arlington, v. 13, n. 2, p. 141-162, 1999. 
STORNI, C. Multiple forms of appropriation in self-monitoring technology: reflections on the role of evaluation in future self-care. International Journal of Human - Computer Interaction, Abingdon, v. 26, n. 5, p. 537-561, 2010.

VALIM, T. Ele sente tudo que a gente sente: um olhar antropológico sobre a sociabilidade de bebês nascidos com a Síndrome Congênita do Zika Vírus em Recife/PE. Monografia (Graduação em
Antropologia) - Departamento de Antropologia, Instituto de Ciências Sociais, Universidade de Brasília, Brasília, DF, 2017.

VELHO, G. Observando o familiar. In: NUNES, E. O. (Org.). A aventura sociológica: objetividade, paixão, improviso e método na pesquisa social. Rio de Janeiro: Zahar, 1978. p. 36-47.

WAGNER, R. A invenção da cultura. São Paulo: Cosac Naify, 2010.

\section{Contribuição das autoras}

Fleischer, na companhia de estudantes de graduação e mestrado em Antropologia da UnB e da UFPE, fez a pesquisa de campo. Fleischer e Carneiro organizaram os dados, planejaram o argumento central do artigo e o escreveram conjuntamente.

\section{Agradecimentos}

Somos gratas às mulheres e as famílias que demonstraram interesse em dialogar conosco nesses últimos quatro anos de pesquisa de campo na Grande Recife/PE; às estudantes que foram conosco pesquisar em Pernambuco e que estiveram conosco no Distrito Federal; aos nossos financiadores, departamentos e universidade.

Recebido: 19/08/2019

Aprovado: 03/02/2020 